\title{
Pterobothrium crassicolle parasitizing Paralichthys orbignyanus (Osteichthyes, Paralichthyidae) in Brazil
}

\author{
NILZA N. FELIZARDO ${ }^{1}$, MARCELO KNOFF ${ }^{2}$, JESSICA B. DINIZ ${ }^{1}$, EDUARDO J.L. \\ TORRES ${ }^{3}$, FLÁVIA A.A. CALIXTO ${ }^{4}$ and SÉRGIO C. SÃO CLEMENTE ${ }^{1}$ \\ ${ }^{1}$ Laboratório de Inspeção e Tecnologia do Pescado, Faculdade de Medicina Veterinária, Universidade \\ Federal Fluminense, Rua Vital Brasil, 64, Vital Brazil, 24320-340 Niterói, RJ, Brazil \\ ${ }^{2}$ Laboratório de Helmintos Parasitos de Vertebrados, Instituto Oswaldo Cruz - FIOCRUZ, \\ Avenida Brasil, 4365, Manguinhos, 21040-900 Rio de Janeiro, RJ, Brazil \\ ${ }^{3}$ Laboratório de Helmintologia Romero Lascasas Porto, Universidade do Estado do Rio de Janeiro, Rua \\ Professor Manuel de Abreu, 444, $5^{\circ}$ andar, Vila Isabel, 20550-170 Rio de Janeiro, RJ, Brazil \\ ${ }^{4}$ Fundação Instituto de Pesca do Estado do Rio de Janeiro, Praça Fonseca Ramos, \\ s/n, Sobreloja, Centro, 24030-020 Niterói, RJ, Brazil
}

Manuscript received on May 4, 2017; accepted for publication on December 18, 2017

\begin{abstract}
From September 2014 to November 2015, 30 Paralichthys orbignyanus specimens were obtained from Sepetiba Bay in the municipality of Rio de Janeiro, State of Rio de Janeiro, Brazil. The fishes were necropsied and cestode larvae were recovered from the abdominal cavity, mesentery, and serosas of the stomach, intestine, spleen, liver, kidney and gonads. Nineteen fish were parasitized by a total of 90 trypanorhynch plerocerci. Based on morphological characters, these were identified as Pterobothrium crassicolle. The parasitism indices for $P$. crassicolle on P. orbignyanus, were $63.3 \%$ for prevalence, 4.7 for mean intensity, 3 for mean abundance and 1 to 18 for range of infection. These parasites were studied due to their importance during fish sanitary inspection, if one considers the harm that the repulsive aspect of infected fish may cause to consumers. This is the first record of $P$. crassicolle plerocerci parasitizing $P$. orbignyanus.
\end{abstract}

Key words: Paralichthys orbignyanus, seafood safety, Trypanorhyncha, Brazil.

\section{INTRODUCTION}

The flounder species Paralichthys orbignyanus (Valenciennes, 1839), lives in water that ranges from shallow to just over $20 \mathrm{~m}$ deep, and enters coastal lagoons from Rio de Janeiro, Brazil to Mar del Plata, Argentina. It feeds on pelagic and benthic species of crustaceans, reaches average length of 32

Correspondence to: Marcelo Knoff

E-mail: knoffm@ioc.fiocruz.br $\mathrm{cm}$, and has both high commercial value and great ecological importance (Figueiredo and Menezes 2000).

The order Trypanorhyncha contains a great diversity of species, parasitizing marine fish and invertebrates. Adult worms live in the intestine of elasmobranchs fish, while the larval forms are found in the coelomic cavity, mesentery, visceral serosas and muscles of teleost fish, crustaceans and molluscs cephalopods (Campbell and Beveridge 
1994). Trypanorhynch cestodes in terms of fish sanitary inspection because of their repugnant appearance. According to the Brazilian Industrial and Sanitary Inspection of Products of Animal Origin Regulation, it is considered unsafe to eat the fish with massive muscle infestation by parasites, including those caused by trypanorhynch cestodes (Brasil 1952). It is common to encounter high rates of infection in the muscles, reinforcing the importance of conducting inspections for cestodes in a wide variety of teleost fish (Dollfus 1942, Amato et al. 1990, Pereira Jr 1993, São Clemente et al. 1995, 1997).

In some trypanorhynch species such as Gymnorhynchus gigas (Cuvier, 1817) Rudolphi, 1819 and Molicola horridus (Goodsir, 1841) plerocerci have antigenic components that can provoke anaphylatic episodes in humans (Rodero and Cuéllar 1999, Vázquez-López et al. 2002, Gòmez-Morales et al. 2008). Using murine models, Mattos et al. (2013a, b) demonstrated by inoculation that crude extracts of Pterobothrium heteracanthum Diesing, 1850 and $P$. crassicolle are capable of inducing the production of specific IgE and $\mathrm{IgG}$, so, inducing an allergic reaction in test animals.

In South America, there is one report of trypanorhynch cestode parasitizing the flounder P. orbignyanus; a Grillotia sp. plerocercus, in Argentina (Alarcos and Etchegoin 2010). In Brazil, species from this cestode order have been reported from other species of flounders, such as P. isosceles Jordan, 1890, P. patagonicus Jordan, 1889 and Xystreurys rasile (Jordan, 1891), which have been found parasitized with plerocercoids of Nybelinia lingualis (Cuvier, 1817) Dollfus, 1927, N. erythraea Dollfus, 1960, Heteronybelinia nipponica (Yamaguti, 1952) Palm, 1999, and plerocerci of Grillotia carvajalregorum (Carvajal and Rego, 1983) Menoret and Yvanov, 2009, Otobothrium sp., Pterobothrium crassicolle Diesing, 1850, P. heteracanthum Diesing, 1850 and Callitetrarhynchus gracilis (Rudolphi, 1819) Pintner, 1931 (Felizardo et al. 2010, Fonseca et al. 2012).

The aim of this study was to identify the species of trypanorhynch parasitizing P. orbignyanus, collected from Sepetiba Bay, municipality of Rio de Janeiro, State of Rio de Janeiro, Brazil, their parasitism indices and infection sites, and to discuss the zoonotic importance of such infections.

\section{MATERIALS AND METHODS}

From September 2014 to November 2015, 30 specimens of the flounder $P$. orbignyanus were collected by professional fishermen in Sepetiba Bay, municipality of Rio de Janeiro, State of Rio de Janeiro, Brazil. All were $32-53 \mathrm{~cm}$ in length. The fish were transported in isothermal boxes to the Laboratory of Fish Inspection Technology of the Veterinary Medicine School of Fluminense Federal University, where they were necropsied and filleted. The fish species was identified according to Figueiredo and Menezes (2000).

Trypanorhynch plerocerci were collected and transferred to a Petri dish with $0.65 \% \mathrm{NaCl}$ solution, and opened with the aid of sharp needles under the stereomicroscope to release the larvae. These were then put in the refrigerator for at least $24 \mathrm{~h}$ to allow the scolices to relax and to promote tentaculare version. Larvae were subsequently fixed in cold AFA, stained with Langeron's carmine, clarified in beechwood creosote, and preserved as whole mounts on Canada balsam, following Knoff and Gomes (2012). For morphologic studies, whole mounts were studied using a bright-field Olympus BH-2 microscope. For scanning electron microscope (SEM) studies, fixed samples were dehydrated in graded ethanol series $\left(70-100^{\circ} \mathrm{GL}\right)$ for one hour each step, dried using critical-point $\mathrm{CO}_{2}$, coated with gold and analyzed with a JEOL 5320 scanning electron microscope operating at an acceleration voltage of $15 \mathrm{kV}$. Trypanorhyncha 
classification was based on Palm (2004), and the species identification of collected plerocerci was based on São Clemente (1986), Rego (1987), Campbell and Beveridge (1996). Indices of parasitic prevalence, mean intensity and mean abundance were calculated according to Bush et al. (1997). Representative specimens were deposited in the Helminthological Collection of the Oswaldo Cruz Institute (CHIOC), FIOCRUZ, Rio de Janeiro, RJ, Brazil.

\section{RESULTS}

From the 30 P. orbignyanus specimens from Sepetiba Bay, nineteen were parasitized by a total of 90 plerocerci of Trypanorhynch cestodes in the abdominal cavity, mesentery, and serosas of the stomach, intestine, spleen, liver, kidney and gonads. (Figure 1a). The specimens were taxonomical identified as belonging to the family Pterobothriidae Pintner, 1931, genus Pterobothrium Diesing, 1850, species $P$. crassicole Diesing, 1850, based on morphological characters observed by bright-field and scanning electronic microscope (Figures 1b-d). Specimens from the current study had plerocerci each with blastocist. Elongate scolex, acraspedote; bothria, pyriform, on mobile pedicels, in cruciform arrangement; pedunculus scolecis subcylindrical, narrower than pars bothrialis; principal rows of metabasal armature form an alternating half-spiral of 5 large heteromorphous, hollow, hooks, with small interpolated hooks between principal rows on bothrial and antibothial surfaces; distinctive basal armature and swelling present on internal and external surfaces of tentacle, macro hooks present on internal surface, asymmetrical basal swelling of tentacle present; hook files 1(1') widely separated, falciform; intercalary row (s) present proximal to each principal row; intercalary rows extend onto external surface to merge with band of hooks occupying midline of tentacle external

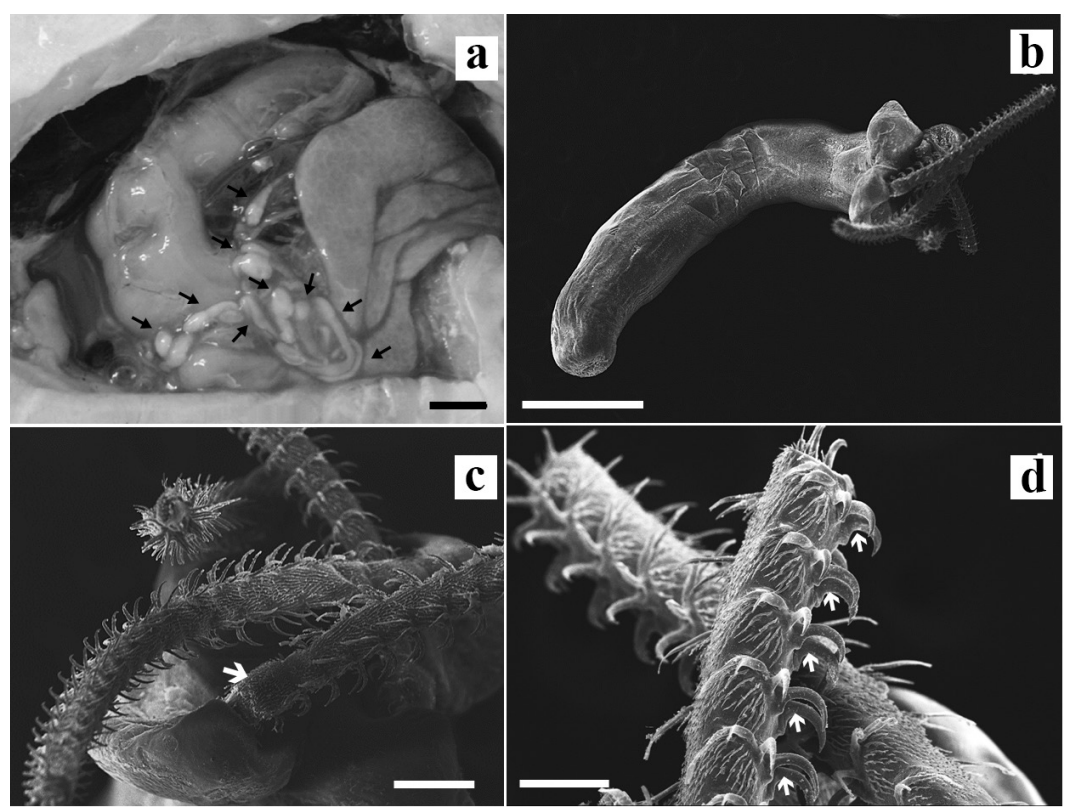

Figure 1 - Pterobothrium crassicolle plerocerci parasitizing Paralichthys orbignyanus: a. Plerocerci in the visceral serosas (arrows). b-d. Plerocercus by scanning electron microscopy. b. Entire worm. c. Distinctive basal armature with swelling on the external surface of tentacle (arrow). d. Falciformes macrohooks row on the internal face of tentacle (arrows). The scale bars in $\mathbf{a}=0.5 \mathrm{~cm}, \mathbf{b}=1 \mathrm{~mm}$, c $=200 \mu \mathrm{m}$ and $\mathbf{d}=100 \mu \mathrm{m}$. 
surface; sheat shighly sinuous; bulbs elongate; pars postbulbosa present.

The parasitism indices for $P$. crassicolle from $P$. orbignyanus, were $63.3 \%$ for prevalence, 4.7 for mean intensity, 3 for mean abundance and 1 to 18 for range of infection. Specimens were deposited in the CHIOC (accession numbers 38.441 and 38442). Some fish had a large number of cestodes, giving a repugnant aspect (Figure 1a). Following eversion, all plerocerci were alive and showed moderate motility.

\section{REMARKS}

Collected $P$. crassicolle specimens from the current study are in accordance with the morphological features of species appearing in previous redescriptions and revisions (São Clemente 1986, Rego 1987, Campbell and Beveridge 1996, Dias et al. 2011, Zuchinalli et al. 2016).

To confirm the species identification of specimens collected in the present study, additional comparisons were made with whole mounted voucher specimens of $P$. crassicolle deposited in the CHIOC: 32253 of Bagre marinus, 32254 of Zungaro zungaro and 37845 of Gobioides broussonetti from State of Pará; 33902 of Micropogonias furnieri from State of Rio Grande do Sul; 33622, 33689-90, 38215-16 of Oligoplites palometa, 35632 of Scomberomorus cavala, 37354 of Paralichthys isosceles and 37750-51 of $P$. patagonicus from State of Rio de Janeiro.

\section{DISCUSSION}

Pterobothrium crassicolle has been reported in several teleost fish worldwide (Bates 1990, Palm 2004, Palm and Bray 2014). In Brazil, there are a number of records of this species in teleosts (Porto et al. 2009, Felizardo et al. 2010, Silva Júnior 2010, Dias et al. 2011, Fonseca et al. 2012, Videira et al. 2013, Zuchinalli et al. 2016), but this is the first record of $P$. crassicolle plerocercus parasitizing $P$. orbignyanus.

Comparing the parasitism indices of $P$. crassicolle of the present study with those found in other species of Paralichthys collected in the State of Rio de Janeiro, showed that in $P$. isosceles and $P$. patagonicus the parasitism indices were lower, with prevalences of $1.7 \%$ and $29.6 \%$, intensity/ mean intensities of 4 and 2.5, and abundance/ mean abundance of 0.07 and 0.74 , respectively (Felizardo et al. 2010, Fonseca et al. 2012). The intensity and the range of infection in the present study was higher than that reported in $P$. isosceles and P. patagonicus in the State of Rio de Janeiro (1 and 1-4 parasites per host) (Felizardo et al. 2010, Fonseca et al. 2012). Pterobothrium crassicolle parasititized $P$. patagonicus at the same infection sites reported in the present study, as well as being present in the abdominal musculature, while $P$. isosceles was found only in stomach serosa (Felizardo et al. 2010, Fonseca et al. 2012). According to Luque et al. (2004), some factors, such as host body size, feeding habits and habitat, are closely linked to parasitism indices, and this could have influenced these results, obtained from conspecific host species in the same ecoregion.

Comparison of our data with that from hosts from other fish families collected in Brazil, showed higher prevalences of $P$. crassicolle in the present study, in Micropogonias furnieri (66.7\%) from State of Rio Grande do Sul (Pereira Jr and Boeger 2005), in Plagioscion squamosissimus (78.6\%) from State of Amapá (Silva Júnior 2010), in Gobioides broussonnetii (80.0\%) from State of Pará (Videira et al. 2013), this latter host had slightly higher prevalence than in the present study. Mean intensity data reported for M. furnieri (5.15) from State of Rio Grande do Sul (Pereira Jr and Boeger 2005) was similar to that of the present study. However, lower indices of mean intensity/ intensity than those of the present study were reported for G. broussonnetii (1.04) from State 
of Pará and Oligoplites saurus (1) from Sepetiba Bay, State of Rio de Janeiro (Videira et al. 2013, Zuchinalli et al. 2016).

In the present study prevalence and range of infection of $P$. crassicole in the flounder $P$. orbignyanus were high, even though it was not found infecting the musculature. This Trypanorhynch species gave a repugnant aspect to the fish, due to the large size of the blastocyst, especially when it was present in great numbers. Another hygienic-sanitary aspect relevant to public health is that the crude extracts of $P$. heteracanthum and $P$. crassicolle are capable of inducing an allergic reaction in humans.

\section{ACKNOWLEDGMENTS}

The authors would like to thank Mr. Isaac Albert Mallet for technical support, and Dr. Marcia Christina Amorim Moreira Leite, head of the Laboratório de Microscopia Eletrônica do Instituto de Química - Universidade do Estado do Rio de Janeiro, for making the scanning electron microscope available. This work was supported by two fellowships: Conselho Nacional de Desenvolvimento Científico e Tecnológico (CNPq) grant number 308048/2013-0 (for S.C.S.C.); and Coordenação de Aperfeiçoamento de Pessoal de Nível Superior (CAPES) grant number EXPPD000020 (for N.N.F.).

\section{REFERENCES}

ALARCOS AJ AND ETCHEGOIN JA. 2010. Parasite assemblages of estuarine-dependent marine fishes from Mar Chiquita coastal lagoon (Buenos Aires Province, Argentina). Parasitol Res 107: 1083-1091.

AMATO JFR, SÃO CLEMENTE SC AND OLIVEIRA GA. 1990. Tentacularia coryphaenae Bosc, 1801 (Eucestoda: Trypanorhyncha) in the inspection and technology of the skipijack tuna, Katsuwonus pelamis (L.) (Pisces: Scombridae). Atlântica 12: 73-77.

BATES RM. 1990. A Checklist of the Trypanorhyncha (Platyhelminthes: Cestoda) of the World (1935-1985). Cardiff: National Museum of Wales, Zoological series n.1, $218 \mathrm{p}$.
BRASIL. 1952. Ministério da Agricultura, Pecuária e Abastecimento. Decreto $N^{\circ} 30.691$, de 29 de Março de 1952. Aprova o novo Regulamento da Inspeção Industrial e Sanitária de Produtos de Origem Animal. Diário Oficial da União, Brasília, DF. Seção 1: 10785. 7 Jul.

BUSH AO, LAFFERTY KD, LOTZ JM AND SHOSTAK AW. 1997. Parasitology meets ecology on its own terms. Margolis et al., revisited. J Parasitol 83: 575-583.

CAMPBELL RA AND BEVERIDGE I. 1994. Order Trypanorhyncha Diesing, 1863. In: Khalil LF, Jones A and Bray RA (Eds), Keys to the cestodes parasites of vertebrates. Cambridge: CABI, Chapter 7, p. 51-148.

CAMPBELL RA AND BEVERIDGE I. 1996. Revision of the family Pterobothriidae Pintner, 1931 (Cestoda: Trypanorhyncha). Invertebr Taxon 10: 617-662.

DIAS JJE, SÃO CLEMENTE SC, PINTO RM AND KNOFF M. 2011. Anisakidae nematodes and Trypanorhycha cestodes of hygienic importance infecting the king mackerel Scomberomorus cavalla (Osteichthyes: Scombridae) in Brazil. Vet Parasitol 175: 351-355.

DOLLFUS RP. 1942. Études critiques sur les Tétrarhynches du Museúm de Paris. Arch Mus Natl Hist Nat 19: 1-466.

FELIZARDO NN, TORRES EJL, FONSECA MCG, PINTO RM, GOMES DC AND KNOFF M. 2010. Cestodes of the flounder Paralichthys isosceles Jordan, 1890 (Osteichthyes - Paralichthyidae) from the State of Rio de Janeiro, Brazil. Neotrop Helminthol 4: 113-125.

FIGUEIREDO JL AND MENEZES NA. 2000. Manual de peixes marinhos do Sudeste do Brasil, VI. Teleostei n. 5, São Paulo: Museu de Zoologia, Universidade de São Paulo, 116 p.

FONSECA MCG, SÃO CLEMENTE SC, FELIZARDO NN, GOMES DC AND KNOFF M. 2012. Trypanorhyncha cestodes of hygienic-sanitary importance infecting flounders Paralichthys patagonicus Jordan, 1889 and Xystreurys rasile (Jordan, 1891) of the Neotropical region, Brazil. Parasitol Res 111: 865-874.

GÒMEZ-MORALES MA, LUDOVISI A, GIUFFRA E, MANFREDI MT, PICCOLO G AND POZIO E. 2008. Allergenic activity of Molicola horridus (Cestoda, Trypanorhyncha), a cosmopolitan fish parasite, in a mouse model. Vet Parasitol 157: 314-320.

KNOFF M AND GOMES DC. 2012. Metodologia básica para coleta e processamento de helmintos parasitos. In: Molinaro EM, Caputo LFG and Amendoeira MRR (Eds), Conceitos e métodos para formação de profissionais em laboratório de saúde, Rio de Janeiro: EPSJV, IOC, p. 251281.

LUQUE JL, MOUILLOT D AND POULIN R. 2004. Parasite biodiversity and its determinants in coastal marine teleost fish of Brazil. Parasitol 128: 671-682.

MATTOS DPBG, VERICIMO MA AND SÃO CLEMENTE SC. 2013a. O pescado e os cestoides Trypanorhyncha - 
do aspecto higiênico ao potencial alergênico. Vet Not 19: 127-139.

MATTOS DPBG, VERICIMO MA AND SÃO CLEMENTE SC. 2013b. Immunogenic activity of the fish tapeworm Pterobothrium heteracanthum (Trypanoryncha: Pterobothriidae) in BALB/C mice. J Helminthol 88: 1-5.

PALM HW. 2004. The Trypanorhyncha Diesing, 1863, Bogor: PKSPL-IPB Press, 710 p.

PALM HW AND BRAY RA. 2014. Marine fish Parasitology in Hawaii. Westarp \& Partner Digitaldruck: Hohenwarsleben, $302 \mathrm{p}$.

PEREIRA JR J. 1993. O complexo de espécies de Trypanorhyncha (Cestoda) em corvinas Micropogonias furnieri do Rio Grande do Sul. Arq Fac Vet UFRGS 21: 58-70.

PEREIRA JR J AND BOEGER WA. 2005. Larval tapeworms (Platyhelminthes, Cestoda) from sciaenid fishes of the southern coast of Brazil. Zoosystema 27: 5-25.

PORTO CJS, SÃO CLEMENTE SC, FREITAS MQ, SÃO CLEMENTE RRB, KNOFF M AND MATOS E. 2009. Pterobothrium crassicolle (Eucestoda: Trypanorhyncha) em corvinas, Micropogonias furnieri, comercializadas no município de Niterói, Rio de Janeiro, Brasil. Rev Brasil Ci Vet 16: 133-135.

REGO AA. 1987. Redescrição de Pterobothrium crassicolle Diesing, 1850 (Cestoda: Trypanorhyncha) e revalidação da espécie. Mem Inst Oswaldo Cruz 82: 51-53.

RODERO M AND CUÉLLAR C. 1999. Humoral immune responses induced by Gymnornhynchus gigas extracts in BALB/c mice. J Helminthol 73: 239-273.

SÃO CLEMENTE SC. 1986. Plerocercos da Ordem Trypanorhyncha, parasitos de corvina Micropogonias furnieri (Desmarest) no litoral do Estado do Rio de Janeiro. Atas Soc Biol 26: 29-36.

SÃO CLEMENTE SC, MARQUES MC, SERRA FREIRE NM AND LUCENA FP. 1995. Análise do parasitismo de peixe espada, Trichiurus lepturus (L.) do litoral do Rio de Janeiro, Brasil. Parasitol Dia 19: 146-149.

SÃO CLEMENTE SC, SILVA CM AND GOTTSCHELK S. 1997. Prevalência e intensidade de infecção de cestoides Trypanorhyncha em anchovas, Pomatomus saltatrix (L.) do litoral do Rio de Janeiro, Brasil. Parasitol Dia 21: 5457

SILVA JÚNIOR ACS. 2010. Parasitismo por cestoides da Ordem Trypanoryncha na musculatura de Plagioscion squamosissimus Heckel, 1840, Pescada Branca (Perciformes: Sciaenidae) comercializadas em Macapá, PA. Ci Anim Bras 11: 737-742.

VÁZQUEZ-LÓPEZ C, ARMAS-SERRA C, BERNADINA W AND RODRÍGUEZ-CAABEIRO F. 2002. A 24-kDa collagenase from Gymnorhynchus gigas elicits rat ileum hyperreactivity and is a target of humoral responses in mice previously given a single oral dose of parasite extract. Dig Dis Sci 47: 935-942.

VIDEIRA M, VELASCO M, DIAS L, MATOS P, ALMEIDA HDF, COSTA ML, SÃO CLEMENTE SC AND MATOS E. 2013. Gobioides broussonnetii (Gobiidae): A new host for Pterobothrium crassicolle (Trypanorhyncha) on Marajó Island, northern Brazil. Rev Bras Parasitol Vet 22: 398-401.

ZUCHINALLI JC, BARROS LA, FELIZARDO NN, CALIXTO FAA AND SÃO CLEMENTE SC. 2016. Trypanorhyncha cestodes parasites of guaivira important in seafood hygiene. Bol Inst Pesca 42: 704-709. 